\title{
IRRELEVANCE IN EU, UNITED KINGDOM AND SERBIAN PARLIAMENTARY DISCOURSE
}

\author{
Vladimir Ž. Jovanović, Faculty of Philosophy, University of Niš, \\ vladimirz.jovanovic@filfak.ni.ac.rs \\ Milica Radulović, Faculty of Philosophy, University of Niš, \\ milica.radulovic@filfak.ni.ac.rs
}

\begin{abstract}
The focus of this research paper is the analysis of argumentative moves in parliamentary discourse that could be characterised as irrelevance criticisms. The term criticism is preferred to the more rigorous term fallacy as careful scrutiny is always advised before an argument is disqualified as missing the point. For the purpose of this research, an irrelevance criticism typology was devised to correspond to parliamentary discourse, an epistemic genre supposed to give knowledge and solutions to the debated political and legislative issues. The empirical part of the study is based on a cross-cultural corpus of almost 200 instances of irrelevance criticisms identified in six European Union, United Kingdom and Serbian parliamentary debates surrounding the questions addressed in the post-Brexit decade. The research corpus analysis involves the identification of core irrelevance types, their frequencies and implications within MP and MEP contributions in the parliamentary debates observed.
\end{abstract}

Keywords: Parliamentary discourse, Relevance, Irrelevance, English, Serbian.

\section{Introduction}

The research is a contribution to the study of irrelevance in argumentation concerning parliamentary discourse, the type of institutional discourse where law and politics, two important institutional frameworks, are combined (Bayley 2004, 7). Parliamentary discourse belongs to the domain of "epistemic elites" because of "[...] the expertise of the MPs on various social issues, and possibly in opposition to government-controlled knowledge, and also because of the social and political consequences of policies that are assumed to be based on knowledge" (van Dijk 2011, 40). Also, this type of discourse has its rules for turn-taking procedures and the terms of address, and, furthermore, cultural and historical aspects of parliamentary debates should never be forgotten (Bayley 2004, 13-14). "It can thus be 
hypothesised that the social and institutional norms and, perhaps above all, the history of a given culture will determine to some extent the kind of language that can be used in parliament" (Bayley 2004, 14). In view of all these peculiarities, which suggest the inter-textual and inter-contextual nature of parliamentary argumentation, irrelevance criticisms themselves are not irrefutable. However, discovering irrelevances in argumentation is still meaningful because irrelevances may indicate weaknesses in reasoning despite MPs' best efforts to predict and prevent possible counter-argumentation.

The theoretical tenets belong to the informal logic movement, the study of argumentation the aim of which is "to make logic useful" (Johnson 2006) and "[...] develop non-formal standards, criteria, procedures for the analysis, interpretation, evaluation, critique and construction of argumentation in everyday language" (Johnson and Blair 2000, 94). ${ }^{1}$ Informal logic includes different strands of thought, which are all based on the assumption that the full complexity of argument structure and argumentation development cannot be analysed and evaluated without incorporating the dialectic and pragmatic insights into the study of reasoning. ${ }^{2}$ The topic of this research, irrelevance in parliamentary discourse, is particularly interesting as parliament is a "procedural and rhetorical form of doing politics" that can "[...] transcend parliamentary institutions, which do not themselves always act in a parliamentary way" (Palonen 2019, 6).

Two objectives were established for the research. The first objective was to establish a particular typology of irrelevances based on contextualised, real-life examples used during parliamentary debates. The classification of irrelevances is based on Walton's (2008, 102-105) four general dimensions of relevance, global, local, subject matter and probative relevance, and other treatments of the issue have also been considered, particularly the ones provided by Gula (2002), Zarefsky (2005), Tindale (2007) and Bennett (2012). The other aim of this investigation was to conduct an analysis of debates held in three different Parliaments, the European Union, the United Kingdom and Serbian Parliaments. The resulting classifications would be compared and contrasted to determine the similarities and differences in argumentation irrelevances. Thus, the findings could help provide better insight into the problem of how well-founded and argumentatively supported would be the contributions by

\footnotetext{
${ }^{1}$ See Walton (2008), or van Eemeren et al. (2014, 373-423).

${ }^{2}$ See Govier (1987), Hansen (2002, 2011) Johnson (2000), Johnson and Blair (2000), Walton (1989, 2006, 2008).
} 
parliamentary members in the course of parliamentary debates, which could potentially be of benefit to theoreticians, linguists, politicians and political parties, journalists and the general public. Moreover, the research was meant to provide answers to questions such as which types of irrelevances would be dominant in the three sub-corpora, whether certain irrelevances were entirely missing during parliamentary sittings and whether there were typical qualities running in all the considered debates.

As "Parliament does not govern but is the forum for public debate and criticism of the policies and acts of government [...]" (Ryle 2005, 5), it is expected that, although MPs will try to avoid irrelevances, irrelevant contributions will still be an inevitable part of debates, not only due to the provisional nature of argumentation, but also as a product of the competing and conflicting standpoints promoted by the government and the opposition. Thus, the starting assumption of the research was that there would be considerably more irrelevant conclusions in the argumentation of Serbian politicians in comparison to the ones which belong to the UK and EU political milieu due to their longer and better-established democratic and parliamentary tradition. Secondly, a more diversified outcome in terms of different types of irrelevances could be expected within the subcorpora relative to the UK and EU Parliaments since the Serbian legislative body consists of 250 members, while the UK and EU are much larger, with 650 and 715 members, respectively.

\section{Theoretical Background and Related Research}

Informal logic is not concerned solely with the illative, or the premise-conclusion agreement issues in an argument. As van Eeemeren et al. $(2014,377)$ point out, informal logicians discarded the view that the criterion for a good argument was soundness, i.e. the criterion that the argument should have true premises and be valid. The trouble is that the truth of premises is often unknown, and we often replace it with acceptability. Also, argumentation analysis and evaluation should integrate the illative foundation with the dialectical component, which refers to the obligations to respond to criticisms and alternative positions (Hitchcock 2017, 325). The subsection 2.1. addresses parliamentary discourse as a specific institutional setting where the irrelevances were observed. The subsection 2.2 focuses on relevance as one of the key components in the evaluation of argument structure. It also presents Walton's (2008, 102-105) four dimensions of relevance. 


\subsection{Parliamentary discourse}

Walton $(2007,20-25 ; 2008,3-8)$ proposes six types of dialogues, persuasion, inquiry, negotiation, information-seeking, deliberation, the eristic type, and also the seventh, the educational type. Although each model has its specific initial situation and rules of goal-directed procedure, there can be various types of dialogue/dialectical shifts. Parliamentary debates are primarily deliberative communicative activity genres embodied as specific communicative activity types aimed at realizing specific institutional points (van Eemeren and Garssen, 2009, 2-5; van Eemeren 2017, 132). Parliamentary deliberations are frequently argumentative and critical, and other communicative activity genres are present in parliamentary deliberation. Such dialectical shifts can be seen as irrelevant manoeuvrings not based on reasoned argumentation, but actually they are goal-directed and therefore, pragmatically relevant.

Parliamentary deliberations cannot be properly understood without addressing the characteristics of parliament as a specific institutional framework. Institutional frameworks and their rules impose constraints on politicians who also pursue their own aims, and by playing political roles, politicians engage in the political system's tasks and responsibilities (Searing 2012, xxi-xxiii). Similarly, Blomgren and Rozenberg $(2012,3)$ argue that MPs face collective and coherent norms and expectations, which largely rely on conceptions of political representation. Furthermore, political representation is associated with role conflict, "[...] different and contradictory demands towards the holder of a position or a person holding simultaneously more than one position with different role expectations" (Best and Vogel 2012, 49). In other words, when they confront other debatees, MPs simultaneously deal with their own role conflicts. Palonen $(2019,46-$ 47) sees parliament as "[...] a type of dissensual political action, in which the chances of conducting controversies in accordance within a civilised, non-violent procedure are better than in other types of assemblies". Institutions in general are "[...] seen as inextricably linked to power and serving the interests of certain powerful groups" (Mayr $2008,4)$, so dissensus is a natural consequence of conflicting interests.

\subsection{Relevance/Irrelevance}

The specific focus of this research is the relevance of the argument, defined by Walton as "[...] a matter of where the argument is leading in a dialogue". Walton describes the acceptability of premises and the relevance of the argument as dialectical, as they suggest alternative points of view with the power to refute an 
argument. Hitchcock $(2017,443)$ qualifies the criterion of relevance as controversial and recommends treating it as a pragmatic concept, as it contributes to a goal in the context. Also, relevance need not be a necessary condition for a good argument, as an irrelevant premise does not mean that the argument cannot serve its purpose.

Walton $(2008,17)$ characterises failures of relevance as those that "[...] can include providing the wrong thesis, wandering away from the point to be proved, or answering the wrong question in a dialogue". There are different ways to commit irrelevances, and, apropos this, Walton (2008, 82-105) discusses four dimensions of relevance/irrelevance, which has been considerably inspirational to the present study. Global relevance is the global direction of the argument, and the evaluations of this dimension can be made once the argument is concluded. It might happen that the proposition is not relevant to the ultimate conclusion, and sometimes the participant has not made it clear what the ultimate conclusion is. Local relevance is the relationship of particular propositions at single stages of an argument, or the relationship between a pair of propositions in an argument. The answer can be topically and globally related to the question, but it may fail to be locally relevant. Apart from global and local relevance, two more dimensions of relevance are added. One of these is the subjectmatter relevance, which checks whether the premise is connected to the conclusion in terms of the subject matters of the topics of the argument. This is close to what Walton $(2008,88)$ defines as "setting an agenda for a discussion". Finally, probative relevance (pertinence) checks whether the premise counts towards or against the conclusion. Sometimes it is not clear what the arguer would like to prove, and s/he may not be trying to prove anything whatsoever, but only distract the audience, which is known as the red herring fallacy/criticism. The four foregoing dimensions are general categories, and, in the subsection 3.4, a catalogue of twenty specific types of irrelevances was devised that also took into consideration classifications proposed by Gula (2002), Tindale (2007) and Bennett (2012).

\section{Corpus Analysis and Discussion}

The corpus includes 197 irrelevance criticism cases identified in debates in three parliaments, the European, the United Kingdom and Serbian parliaments. The UK and EU sub-corpora are directly topically related. Serbia is not a member state of the EU, but because of the geographical position of Serbia, its political and economic relations with the member states of the European Union are important. Six different speech events were the sources of irrelevances studied here. 
The EU sample relies on three EU parliamentary debates, the UK sample includes two speech events, whereas the Serbian sample includes irrelevances detected in one speech event. As for the EU and UK samples, the records observed were given and analysed in the form of denaturalised transcripts (Bucholtz, 2000; Cribb and Rochford, 2018) of the speech event, considering the fact that argumentation of the contributors, solely verbally expressed and largely based on premise and conclusion indicators, was the central interest of the research. The debate transcripts analysed within the research were considered in their original form, as obtained from the source, the video footage of the debate provided by YouTube video platform and the auto-generated transcript. As regards the Serbian sample, since auto-generated transcripts of Serbian YouTube parliamentary sittings were not available, the stenography transcript was downloaded from the site of the National Assembly of the Republic of Serbia. Two mixed gender researchers examined the material independently and coded the corpus data in the three sub-corpora.

\subsection{The EU sub-corpus}

The first sub-corpus consists of 94 examples of irrelevances from three debates held at the European Parliament in Strasbourg, France. The debates within the EU elected 751-member official legislative body that were considered for this research involve the 2014-2019 Parliamentary term, and in particular three debates, the first one was published on March $13^{\text {th }} 2018$ in connection to the Guidelines on the framework of future EU-UK relations, the second on September $11^{\text {th }}$ 2018, regarding the situation in Hungary and the report submitted by Judith Sargentini, and the third to consider the UK's withdrawal from the European Union. The debates were chosen due to their corresponding importance for the vital interests of the European Union, as the Brexit debate concerned an unprecedented situation of a member state leaving the Union. All of the debates covered issues potentially charged with intricacies and of major impact on the very essence of the EU.

\subsection{The UK sub-corpus}

The second sub-corpus of irrelevances includes 51 examples from two 2018 YouTube auto-generated transcripts of the Prime Minister's Question Time, during which the MPs examine the work of the government. The latest UK general election for 650 MPs in the House of Commons was held in 2017. The first YouTube transcript was published on December $12^{\text {th }} 2018$, and the questions asked in this 
session are those concerning the intensely debated Brexit referendum and negotiations. The second transcript was published on November $22^{\text {nd }} 2018$, and the questions raised were those on the subject of the Brexit draft agreement with the European Union, which included the burning issue of the Irish backstop. The Brexit referendum is dramatically relevant for the future of Europe, and the geopolitical relations in general.

\subsection{The Serbian sub-corpus}

The next speech event is the source of the third sub-corpus, which includes 52 instances identified in the 2018 debate held in the 250-member Parliament, the National Assembly of the Republic of Serbia, during the Parliamentary term that follows the latest election in 2016. The sub-corpus designed for this research is based on the stenography transcript of the continuation of the Second Sitting of the Second Regular Session of the National Assembly of the Republic of Serbia in 2018 - the fifth day [Druga sednica Drugog redovnog zasedanja Narodne skupštine Republike Srbije u 2018. godini - peti dan] convened on October $23^{\text {rd }}, 2018$. The examples are taken from the transcript of the first half of the sitting before the adjournment. The agenda included different bills, some of which are the Bill on Construction Products, submitted by the Government, the Bill on the Confirmation of the Framework Agreement on Economic and Technical Cooperation between the Government of the Republic of Serbia and the Government of Hungary in the Area of Infrastructure Project, submitted by the Government, etc. The temporary stenography transcript, unedited and unauthorised, is available online at the site of the National Assembly of the Republic of Serbia. The list of the bills in the English language brought forward in the Second sitting is available for download. ${ }^{3}$

\subsection{Methods}

The structure of the speech event that served the analytic purposes is largely the same in all of the observed events. The topic on the agenda of the debate in question, which is set beforehand, is announced by the Speaker, who calls upon members to contribute to the debate in a pre-determined order. The participants in the debates include Prime Ministers, Ministers, Opposition leaders or other members of parliament. In the initial or keynote address, an MP/MEP defines a proposal or resolution to be discussed and potentially passed

\footnotetext{
${ }^{3}$ See corpus sources at the end of the paper.
} 
(Arguer 1). This proposal normally contains a kind of proposition. Any MP/MEP contributing to the debate upon the given topic on the agenda is supposed to provide arguments in favour of the proposal from the keynote address or against it (Arguer 2), or at any rate "[...] each arguer must have a side, a thesis or conclusion to be proved as his job in the argument" (Walton, 2008, 105). However, if the contribution does not rely on well-based arguments, solid proof or acceptable reasoning, the argumentation may be considered irrelevant.

One of the methods for the identification of irrelevances was to identify irrelevant premises and conclusions within arguments by means of the premise and conclusion indicators proposed by Walton $(2006,7)$,

a) Premise indicators: since, for, because, given that, for the reason that, seeing that;

b) Conclusion indicators: therefore, thus, hence, consequently, we may conclude that, so, it follows that, accordingly.

Apart from these conjunctions, all synonymous expressions were taken into account as the premise/conclusion indicators. Also, the method known as the "logical minimum (if premise, then conclusion)" "pragmatic optimum" (van Eemeren and Grootendorst 2004, 117-118) was applied to identify premises and conclusions with and without indicators, and to identify both stated and unstated premises and conclusions.

Irrelevances were then arranged in classes in consultation with Walton's $(2008,102-103)$ four general dimensions of relevance and the subtypes of irrelevances developed by Gula (2002), Tindale (2007) and Bennett (2012). Having in mind the existing classifications which may be overly general in certain respects (Walton) or excessively detailed for the observed context (Bennett), a list of criticisms could be proposed which may be considered pertinent in particular to the parliamentary discourse analysis. Walton's four dimensions of relevance could be used as starting points, but further specified in the following manner:

\section{Global irrelevance}

The over-all direction of an arguer's arguments in establishing their thesis in a network of linked arguments is erratic, unproductive or illogical.

1. IRRELEVANT CONCLUSION FROM PREMISES - NON SEQUITUR - A conclusion that is wrong taking into account the given arguer's premises. Also, a 
conclusion based on no premises, not supported by any kind of evidence.

2. IRRELEVANT CONCLUSION - ARGUMENTUM AD NAUSEAM - A needless repetition of an idea in the conclusion, a tautology, especially presented in words other than those of the immediate context in place of better supporting evidence.

3. IRRELEVANT CONCLUSION - ARGUMENTUM AD IGNORANTIAM - The argument that is based on the absence of evidence, but that does not mean that the premise is false.

4. IRRELEVANT CONCLUSION - ARGUMENTUM AD LOGICAM - The conclusion is irrelevant as the truth value of an argument is falsified based on the presumption that the argument contains a fallacy.

5. NON-EXPLANATORY CONCLUSION - OBSCURUM PER OBSCURIUS - Not being able to elucidate or explain the claim made previously, making it even less understandable instead.

\section{Local irrelevance}

Occurs at individual stages of an argument, and may involve the relationship between a question and a reply where a reply to a question is considered to be evasive or irrelevant. Questions, as well as replies, can be found as irrelevant.

6. SIMPLIFIED CONCLUSION TO A COMPLEX PREMISE STRUCTURE - Focusing the attention on certain segments of the argument while completely ignoring or leaving out the others.

7. IRRELEVANT CONCLUSION BASED ON SUPPRESSED EVIDENCE - CHERRY PICKING Trying to select evidence in order to present only the evidence that will convince the others to accept the claim.

8. IRRELEVANT CONCLUSION BASED ON INSUFFICIENT SAMPLE - Drawing a conclusion on the basis of a sample that is not representative of the whole.

III Subject-matter irrelevance

The premise is not connected to the conclusion by sharing some common subject matters of the topics of the argument, nor is the conclusion of an arguer connected to the subject matter of contributions by other participants.

9. DIVERSE TOPICS - The most drastic case when the argument or conclusion is completely in discord with the topic of the arguer's premises or the topic of the debate. 
IV Probative irrelevance

The premise of an arguer does not play a part in proving a conclusion, nor does the conclusion play a part in proving or disproving the premises of other participants.

10. IRRELEVANT CONCLUSION - ARGUMENTUM AD HOMINEM - The feelings that the speaker has toward the arguer are transferred to the argument.

11. IRRELEVANT CONCLUSION - ARGUMENTUM AD BACULUM - The argument is based on the idea that the arguer who holds the power is right. It is the force of coercion or threat that is used to support a conclusion instead of any reasonable evidence.

12. IRRELEVANT CONCLUSION - ARGUMENTUM AD MISERICORDIAM - Trying to focus the attention on the circumstances affecting the arguer or someone else and acquire the pity of the others.

13. IRRELEVANT CONCLUSION - ARGUMENTUM AD VERECUNDIAM - The argument is based on authority (possibly questionable) or celebrity status of another.

14. IRRELEVANT CONCLUSION - ARGUMENTUM AD POPULUM - The argument is based not on any concrete evidence, but on the conviction of a (large) group that a claim is true.

15. IRRELEVANT CONCLUSION - ARGUMENTUM AD NOVITATEM - Claiming that something new or modern is better to the status quo or the previous plan, based exclusively on its newness and providing no other evidence than that.

16. IRRELEVANT CONCLUSION - ARGUMENTUM AD CONSEQUENTIAM - The argument is based the conclusion that a proposition is true or false because the consequences of it being true or false are desirable or undesirable.

17. IRRELEVANT CONCLUSION BASED ON CONFIDENT SPECULATION - The argument is based on the speaker's convictions, beliefs or hopes rather than on evidence suppliEd.

18. DISTRACTION CONCLUSION - RED HERRING - A conclusion of an argument that introduces irrelevant material in order to deflect attention on the current debate and distract it to another issue.

19. EXAGGERATED CONCLUSION TO ARGUER'S PREMISES - Not accurately representing the truth, using inappropriately inflated language, an unnecessary parable or a change of context to refute the argument.

20. IRRELEVANT CONCLUSION BASED ON ANALOGY TO DICTATORSHIP - REDUCTIO AD HITLERUM - Trying to falsify an argument not by providing counterevidence, but by making a parallel between the arguer and dictators or authoritarians. 
The three samples serve as points for comparing and contrasting irrelevance types in the three sub-corpora. The inductive generalizations regarding the number of irrelevance tokens point to the specificities of parliamentary discoursing.

\subsection{Results and Discussion}

This section is devoted to the results of the research. The discussion is based on the frequencies of irrelevances as well as the similarities and differences of the types found in the three samples.

\subsubsection{Irrelevance Frequency}

The analysis of the corpus of data in terms of frequency has shown that the average number of irrelevances per 10,000 words in the corpus amounts to almost 23, or more precisely 22.9. However, when the individual sub-corpora are viewed, the Serbian sub-corpus proved to be the one with the lowest rate of irrelevances on average, scoring 19.5 irrelevances per 10, 000 words. The second segment was the UK sub-corpus with 20.8 irrelevances per 10,000 words, while the most prominent in terms of frequency was the EU part of the corpus with 27.0 irrelevances every 10,000 words. Thus, the immediacy and significance of the topics, and a much wider gamut of political options, approaches and traditions of the debate participants at the EU parliament seem to have affected the final outcome by the arguers' resorting to various irrelevance forms.

This could be illustrated by the example (1) from the EU debate on Hungary and the migrant crisis. Faced with accusations as to "[...] the existence of a clear risk of a serious breach by Hungary of the values on which the Union is founded", Hungary's Prime Minister Victor Orban addressed the forum defending the stance of his government. In response, some of the consecutive arguers introduced various irrelevant elements within their discussions, both in the domain of the so-called Red herring criticism, a) by Guy Verhofstadt from Belgium's Open Vlaamse Liberalen en Democraten and b) by Tanja Fajon from Slovenia's Socialni demokrati,

(1) a. 17:05 inconvenient truth is that under these

17:08 circumstances it would be impossible

$17: 10$ today Mr. Orban that Hungary can join the

17:13 European Union that is the reality of

$17: 16$ today and what you really, I ask you to

17:21 do so because I like Hungary, I like

17:24 certainly the Hungarian literature and

$17: 28$ culture that is in any way to stop to 
b. 55:22 dear Mr. Orban this debate is not against Hungary. Slovenia loves

\section{5:25 Hungary.}

It is not infrequent that in a debate on a grave subject or an acute problem the arguers tend to use less- convincing strategies of argumentation, and not those based on conclusive proof. However, the examples in (1a-b) point out that 'verbal jugglery' can assume various forms, in this particular example, as an attempt on the part of the speakers to ingratiate themselves to the audience or the co-debaters by insisting on verbs such as "to like" and "to love" and thus present their assertions as valid and/or unquestionably impartial.

Table 1 provides the basic findings relative to the three subcorpora, the word count and the aggregate number of irrelevance instances,

\begin{tabular}{|l|l|c|c|c|c|}
\hline CORPUS & SOURCE & $\begin{array}{c}\text { Word } \\
\text { count }\end{array}$ & Percentage & Irrelevances & Percentage \\
\hline \multirow{2}{*}{$\begin{array}{l}\text { EU } \\
\text { sub- } \\
\text { corpus }\end{array}$} & Debate 1 & 13,937 & $16.1 \%$ & 36 & $18.3 \%$ \\
\cline { 2 - 6 } & Debate 2 & 16,034 & $18.7 \%$ & 55 & $27.9 \%$ \\
\cline { 2 - 6 } & Debate 3 & 4,808 & $5.6 \%$ & 3 & $1,5 \%$ \\
\cline { 2 - 6 } & Total & $\mathbf{3 4 , 7 7 9}$ & $\mathbf{4 0 . 4 \%}$ & $\mathbf{9 4}$ & $\mathbf{4 7 . 7 \%}$ \\
\hline \multirow{2}{*}{$\begin{array}{l}\text { UK } \\
\text { sub- } \\
\text { corpus }\end{array}$} & Debate 1 & 6,146 & $\mathbf{7 . 1 \%}$ & 15 & $7.6 \%$ \\
\cline { 2 - 6 } & Debate 2 & 18,358 & $21.4 \%$ & 36 & $18.3 \%$ \\
\cline { 2 - 6 } & Total & $\mathbf{2 4 , 5 0 4}$ & $\mathbf{2 8 . 5 \%}$ & $\mathbf{5 1}$ & $\mathbf{2 5 . 9 \%}$ \\
\hline \multirow{2}{*}{$\begin{array}{l}\text { SER } \\
\text { sub- } \\
\text { corpus }\end{array}$} & Debate 1 & 26,701 & $31.1 \%$ & 52 & $26.4 \%$ \\
\cline { 2 - 6 } & Total & $\mathbf{2 6 , 7 0 1}$ & $\mathbf{3 1 . 1 \%}$ & $\mathbf{5 2}$ & $\mathbf{2 6 . 4 \%}$ \\
\hline
\end{tabular}

Table 1. Word count, percentage and number of irrelevances in the corpus.

\subsubsection{Irrelevance Types}

All of the 20 different types of irrelevances were detected in one form or another, except for argumentum ad ignorantiam, which failed to appear in any of the three sub-corpora. This result may be interpreted as empirical support of the claims regarding the 'epistemic elite' and the qualifications of parliamentary discourse by van Dijk $(2011,40)$. Although this type may "[...] feature prominently in public discussion about terrorism" (Zarefsky, 2014,268) and political campaigning, it seems to be much avoided during talks within the parliament. Moreover, none of the other types emerges as significantly 
preponderant in the corpus, which makes a statement that the arguers in the debates surveyed were more inclined toward using a wide array of forms to criticise their competitors or using a variety of irrelevances. The results clearly show that the three most frequent types registered in the corpus were non-sequitur, argumentum ad hominem and argumentum ad verecundiam. It is evident from the data provided below that these three types make the core of what could be called the 'common denominator' of irrelevance in the parliamentary discourse studied here, as they are accountable for more than $45 \%$ of the total corpus of irrelevances. The additional five types that were present in all the sub-sections of the corpus include argumentum ad nauseam, argumentum ad consequentiam, simplified conclusion, cherry picking and irrelevance based on confident speculation. If parliamentary discourse were to be described in terms of irrelevancies established upon this common core which encompasses two thirds of all the cases, the outcome would be the following, the MPs have a pronounced tendency to be selective while simultaneously insisting on promoting claims based on the authority of others or personal convictions rather than on more concrete evidence or other forms of persuasion.

The ratios of the irrelevance types and their presence within the corpus are presented in Table 2. Moreover, the table shows the distribution of irrelevance types in the sub-corpora,

\begin{tabular}{|l|l|c|c|c|c|c|c|c|c|}
\hline \multirow{2}{*}{} & \multirow{2}{*}{ IRRELEVANCE TYPE } & \multicolumn{9}{|c|}{ CORPUS } \\
\cline { 3 - 10 } & & \multicolumn{2}{|c|}{ EU } & \multicolumn{3}{|c|}{ UK } & \multicolumn{2}{c|}{ Serbian } & \multicolumn{2}{c|}{ Total } \\
\cline { 3 - 10 } & No & \% & No & No & No & \% & No & \% \\
\hline 1. & Non sequitur & 15 & 15.96 & 9 & 17.65 & 8 & 15.38 & $\mathbf{3 2}$ & $\mathbf{1 6 . 2 4}$ \\
\hline 2. & $\begin{array}{l}\text { Argumentum ad } \\
\text { nauseam }\end{array}$ & 8 & 8.51 & 6 & 11.76 & 4 & 7.69 & $\mathbf{1 8}$ & $\mathbf{9 . 1 3}$ \\
\hline 3. & $\begin{array}{l}\text { Argumentum ad } \\
\text { hominem }\end{array}$ & 12 & 12.76 & 13 & 25.49 & 5 & 9.61 & $\mathbf{3 0}$ & $\mathbf{1 5 . 2 3}$ \\
\hline 4. & $\begin{array}{l}\text { Argumentum ad } \\
\text { baculum }\end{array}$ & 2 & 2.13 & 0 & 0 & 0 & 0 & $\mathbf{2}$ & $\mathbf{1 . 0 1}$ \\
\hline 5. & $\begin{array}{l}\text { Argumentum ad } \\
\text { ignorantiam }\end{array}$ & 0 & 0 & 0 & 0 & 0 & 0 & $\mathbf{0}$ & $\mathbf{0}$ \\
\hline 6. & $\begin{array}{l}\text { Argumentum ad } \\
\text { misericordiam }\end{array}$ & 1 & 1.06 & 0 & 0 & 0 & 0 & $\mathbf{1}$ & $\mathbf{0 . 5 0}$ \\
\hline 7. & $\begin{array}{l}\text { Argumentum ad } \\
\text { verecundiam }\end{array}$ & 12 & 12.76 & 3 & 5.88 & 13 & 25 & $\mathbf{2 8}$ & $\mathbf{1 4 . 2 1}$ \\
\hline 8. & $\begin{array}{l}\text { Argumentum ad } \\
\text { populum }\end{array}$ & 1 & 1.06 & 0 & 0 & 2 & 3.85 & $\mathbf{3}$ & $\mathbf{1 . 5 2}$ \\
\hline 9. & $\begin{array}{l}\text { Argumentum ad } \\
\text { novitatem }\end{array}$ & 0 & 0 & 0 & 0 & 1 & 1.92 & $\mathbf{1}$ & $\mathbf{0 . 5 0}$ \\
\hline 10. & $\begin{array}{l}\text { Argumentum ad } \\
\text { logicam }\end{array}$ & 0 & 0 & 0 & 0 & 2 & 3.85 & $\mathbf{2}$ & $\mathbf{1 . 0 1}$ \\
\hline
\end{tabular}




\begin{tabular}{|c|l|c|c|c|c|c|c|c|c|}
\hline 11. & $\begin{array}{l}\text { Argumentum ad } \\
\text { consequentiam }\end{array}$ & 2 & 2.13 & 2 & 3.92 & 1 & 1.92 & $\mathbf{5}$ & $\mathbf{2 . 5 4}$ \\
\hline 12. & $\begin{array}{l}\text { Irrelevance based on } \\
\text { insufficient sample }\end{array}$ & 2 & 2.13 & 0 & 0 & 1 & 1.92 & $\mathbf{3}$ & $\mathbf{1 . 5 2}$ \\
\hline 13. & $\begin{array}{l}\text { Irrelevance based on } \\
\text { confident speculation }\end{array}$ & 6 & 6.38 & 4 & 7.84 & 3 & 5.77 & $\mathbf{1 3}$ & $\mathbf{6 . 6 0}$ \\
\hline 14. & Red herring & 13 & 13.82 & 0 & 0 & 1 & 1.92 & $\mathbf{1 4}$ & $\mathbf{7 . 1 0}$ \\
\hline 15. & $\begin{array}{l}\text { Obscurum per } \\
\text { obscurius }\end{array}$ & 1 & 1.06 & 6 & 11.76 & 0 & 0 & $\mathbf{7}$ & $\mathbf{3 . 5 5}$ \\
\hline 16. & $\begin{array}{l}\text { Exaggerated } \\
\text { conclusion }\end{array}$ & 7 & 7.45 & 0 & 0 & 4 & 7.69 & $\mathbf{1 1}$ & $\mathbf{5 . 5 8}$ \\
\hline 17. & Simplified conclusion & 4 & 4.25 & 1 & 1.96 & 1 & 1.92 & $\mathbf{6}$ & $\mathbf{3 . 0 4}$ \\
\hline 18 & Reductio ad Hitlerum & 2 & 2.13 & 0 & 0 & 0 & 0 & $\mathbf{2}$ & $\mathbf{1 . 0 1}$ \\
\hline 19. & Cherry picking & 3 & 3.19 & 7 & 13.72 & 3 & 5.77 & $\mathbf{1 3}$ & $\mathbf{6 . 6 0}$ \\
\hline $\mathbf{2 0 .}$ & Diverse topics & 3 & 3.19 & 0 & 0 & 3 & 5.77 & $\mathbf{6}$ & $\mathbf{3 . 0 4}$ \\
\hline & Total & $\mathbf{9 4}$ & $\mathbf{1 0 0 \%}$ & $\mathbf{5 1}$ & $\mathbf{1 0 0 \%}$ & $\mathbf{5 2}$ & $\mathbf{1 0 0 \%}$ & $\mathbf{1 9 7}$ & $\mathbf{1 0 0 \%}$ \\
\hline
\end{tabular}

Table 2. Number and percentage of irrelevance types in the subcorpora.

The dominant type is the one that implies a statement or conclusion that does not logically follow from or is not clearly related to any of the premises or anything previously exposed by other arguers. In the context of the difficult Brexit talks, conclusions in the form of questions need not be always based on any premises nor on the claims of any of the previous arguers, not even substantiated in any way as illustrated by (2) in the contribution by Marcus Pretzell from Germany's Die blaue Partei at the EU parliamentary debate on the EU-UK future relations. The honourable MEP, apparently not supportive of Brexit, urged his colleagues in a particular way to be less stringent in their attempts to hinder the process,

37:25 Ladies and gentleman, if Great Britain

$37: 28$ will be better off because of the

37:30 withdrawal why do you have such fears of

37:33 the UK coming out better

$37: 37$ if you don't prevent it and that's what

37:39 it's about for you in this debate.

The following examples are two more instances of non-sequitur, found in the UK and the Serbian sub-corpora, (3) Theresa May's contribution on internal UK issues regarding trade union legislature, during the Prime Minister's Question Time; and (4) the contribution by Milena Turk, the Serbian Progressive Party MP (in Serbian, Srpska napredna stranka - SNS), which also includes an example of 
argumentum ad verecundiam and the exaggerated conclusion (the English translation follows the Serbian transcript),

(2) 9:51 The Prime Minister, Businesses will be affected by the fact that the shadow Chancellor

9:55 wants to change the law so that trade unions in this country

can go on strike in solidarity

10:02 with any strike anywhere in the world. That may be solidarity with trade unions. It is

10:11 not solidarity with small businesses, and it is not solidarity with the ordinary working

10:15 people who would pay the price of Labour.

(3) Kada je reč o ravnomernom razvoju Republike Srbije i generalno o unapređenju poslovanja, politika koju vode Aleksandar Vučić i SNS dovela je do toga da mi danas širom Srbije imamo gradilišta. Nema grada i opštine u kojima se ne radi na izgradnji nove infrastrukture, na obnavljanju postojeće infrastrukture i danas imamo situaciju da se ravnomerno ulaže u svaki grad, svaku opštinu, svaki okrug. Nema više povlašćenih, kao što smo zaista bili svedoci da je to bio slučaj u ranijim režimima.

[When it comes to balanced development of the Republic of Serbia, and to business development in general, the politics led by Aleksandar Vučić and SNS has led to a situation where we have construction sites all over Serbia (ad verecundiam). There is no city or municipality without either a new infrastructure under construction or without the existing infrastructure under renovation, so today, we have a balanced investment in all cities, all municipalities, all regions (exaggeration). No one is privileged any more, as indeed witnessed in the previous regimes.]

Another important implication is that the variety of irrelevance types is also greater within the EU sub-corpus in comparison to the other two segments. Namely, there are 17 representative irrelevance models (or $85 \%$ of all) in the EU parliamentary discourse (with only argumentum ad ignorantiam, argumentum ad novitatem and argumentum ad logicam missing), whereas there are only 9 (or 45\%) in the UK and 15 (or 75\%) in the Serbian sub-corpora. As the samples of parliamentary debates from the Serbian and the UK Parliament are 
comparatively similar in size, it is obvious that Serbian MPs proved to be considerably more diversified in their employment of irrelevances.

As for the separate sub-corpora viewed individually, the overall result is similar, but not precisely reflected by the three segments. In the Serbian sample, the argumentum ad verecundiam was second to none (see example 4 with three irrelevances including the ad verecundiam type), whereas non-sequitur was followed by argumentum ad hominem. This speaks in favour of the idea that arguments in the Serbian parliament may be much more based on political and other kinds of authority than on solid facts. In contrast, the UK parliamentary debates were characterised by irrelevances such as argumentum ad hominem, non-sequitur and cherry-picking. This is not surprising, as they are all reflections of the battle between political parties, the Conservative and the Labour in this case,

(4) The Prime Minister [...] I am interested

3:33 that the right hon. Gentleman wants to know what progress we have made:

because actually

3:38 he could not care less what I bring back from Brussels. He has been clear that whatever

3:47 comes back from Brussels he will vote against it, because all he wants to do is create Chaos

3:54 in our economy, division in our society and damage to our economy. That's Labour.

4:20 That's Corbyn.

Finally, in the segment encompassing EU Parliament debates, the positioning of the main types of irrelevances is somewhat different, as the non-sequitur type was followed by the distraction conclusion (red herring), where emotions are also manipulated without providing any tenable evidence to support one's claim. The third position was equally divided between two types of irrelevances based on authority and personality. Most of the ad hominem argument irrelevances were directed to the person of the Hungarian Prime Minister Mr. Victor Orban from the Fidesz - Magyar Polgári Szövetség party. However, some of these can be counted as circumstantial ad hominem which entails individuals who "[...] must abandon their premises in order to be consistent" (Zarefsky, 2014,192).

\section{Conclusion}

The results show that the basic hypothesis of the entire research that there would be considerably more irrelevance types in the 
argumentation of Serbian politicians in comparison to the ones which belong to the UK and EU political milieu was not confirmed. In contrast, it was the parliamentary discourse of the EU Parliament that yielded the highest number of irrelevances on average (Serbian, 0.19 per Word Count; UK, 0.20 per Word Count; EU, 0.27 per Word Count). The result shows that the EU parliament arguers used most irrelevance types in their debating. Dissensual views in parliament are expected, but they can also complicate the relations among MEPs and create a crisis of confidence. Irrelevances in the other two sub-corpora should also be viewed as a reflection of numerous dissensual views. Moreover, the hypothesis that a more diversified outcome in terms of different types of irrelevances could be expected within the subcorpora relative to the UK and EU Parliaments was only partially verified, as the UK sample registered less than $50 \%$ of all the established types of irrelevance, while the Serbian yielded $75 \%$ of the types and EU sample as much as $85 \%$ of the available classes.

As for the specificities of the irrelevance types, the following results were obtained. The three dominant types established were 1) non-sequitur (Serbian, 15.38\%, UK, 17.65\%, EU, 15.96\%), 2) argumentum ad hominem (Serbian, 9.61\%, UK, 25.49\%, EU, 12.76\%) and 3) argumentum ad verecundiam (Serbian, 25\%, UK, 5.88\%, EU, $12.76 \%)$. The first type, non-sequitur has the most similar rate of occurrence in the three samples among the three given types of irrelevances. This shows problems in connecting premises to the conclusion while defending/ justifying one's own and attacking the opponent's actions. The high frequency of argumentum ad hominem was not a surprise, as the political opponent's credibility is one of the major targets in a political attack. As far as this type is concerned, the highest frequency was found in the UK sample. The third most frequent type is the appeal to authority, with the highest rate of occurrence in the Serbian sample. Finally, another specificity should be mentioned, and it is the frequency of the red herring irrelevance. It was the members of the European Union Parliament who thought that the red herring was a more expressive argumentative device than the members of the other two parliaments (EU, 13.82\%, Serbian, 1.92\% and UK, 0\%). The disinclination of UK MPs to resort to this type of contribution is the reason why red herring is not one of the eight types of irrelevances isolated in this study that could be counted as characteristic or definitive of parliamentary discourse in general.

To conclude, the results of the research show that the construction of arguments in real time is unpredictable as the basic hypothesis was not confirmed. However, empirical research can lead 
to inductive generalizations that offer insight into the real world of argumentation plus provide direction for further investigation. The detected discrepancies and peculiarities in the three sub-corpora are also important findings, as they suggest what specific lines of reasoning were identified while MPs and MEPs promoted their own and criticised someone else's positions.

\section{References}

Bayley, Paul. "The Whys and Wherefores of Analysing Parliamentary Discourse." Cross-Cultural Perspectives in Parliamentary Discourse, Ed. Paul Bayley. Amsterdam: John Benjamins, 2004. 1-44.

Bennett, Bo. Logically Fallacious - The Ultimate Collection of over 300 Logical Fallacies. Sudbury, MA: eBooklt.com, 2012.

Best, Heinrich and Lars Vogel. "The Emergence and Transformation of Representative Roles." Parliamentary Roles in Modern Legislatures, Ed. Magnus Blomgren and Olivier Rozenberg. London: Routledge, 2012. 37-65.

Blomgren, Magnus and Olivier Rozenberg. "Introduction." Parliamentary Roles in Modern Legislatures, Ed. Magnus Blomgren and Olivier Rozenberg. London: Routledge, 2012. 1-7.

Bucholtz, Mary. "The Politics of Transcription." Journal of Pragmatics 32(2000): 1439-1465.

Cribb, Michael V. and Shivani Rochford. "The Transcription and Representation of Spoken Political Discourse in the UK House of Commons". International Journal of English Linguistics. 8. 2 (2018): 1-14.

van Dijk, Teun A. "Discourse, Knowledge, Power and Politics, Towards Critical Epistemic Discourse Analysis." Critical Discourse Studies in Context and Cognition. Ed. Christopher Hart. Amsterdam: John Benjamins, 2011. 27-63.

van Eemeren, Frans H. "Strategic Manoeuvring in Argumentative Discourse in Political Deliberation." In Contextualizing PragmaDialectics, Ed. Frans $\mathrm{H}$. van Eemeren and Wu Peng. Amsterdam: John Benjamins, 2017. 123-144.

van Eemeren, Frans H., and Bart Garssen. "In Varietate Concordia United in Diversity, European Parliamentary Debate as an Argumentative Activity Type." Controversia 7.1 (2009): 19-37. van, Eemeren, Frans H., and Rob Grootendorst. A Systematic Theory of Argumentation, the Pragma-dialectical Approach. Cambridge: Cambridge UP, 2004.

van Eemeren, Frans $\mathrm{H}$. et al. Handbook of Argumentation Theory. Dordrecht: Springer, 2014. 
Hitchcock, David. On Reasoning and Argument. Cham: Springer, 2017.

Govier, Trudy. Problems in Argument Analysis and Evaluation. Dordrecht: Foris, 1987.

Gula, Robert. J. Non-sense. A Handbook of Logical Fallacies. Edinburg: VA, Axios, 2002.

Hansen, Hans V. "An Exploration of Johnson's Sense of Argument." Argumentation 16.3 (2002): 263-276.

Hansen, Hans V. "Notes on Balance-of-consideration Arguments." Conductive Argument. An Overlooked Type of Defeasible Reasoning, Ed. Johnson A. Blair and Ralph H. Johnson. London: College Publications, 2011. 31-51

Johnson, Ralph H. Manifest Rationality. A Pragmatic Theory of Argument. Mahwah, NJ: Lawrence Erlbaum, 2000.

Johnson, Ralph H., and Blair J. Anthony. "Informal Logic. An Overview." Informal Logic 20.2 (2000): 93-107.

Johnson, Ralph H. "Making Sense of Informal Logic." Informal Logic 26.3 (2006): 231-258.

Mayr, Andrea. "Introduction, Power, Discourse and Institutions." In Language and Power, An Introduction to Institutional Discourse, Ed. Andrea Mayr. London, Continuum, 2008. 1-25.

Palonen, Kari. Parliamentary Thinking, Procedure, Rhetoric and Time. Cham: Palgrave Macmillan, 2019.

Ryle, Michael. "Forty Years on and a Future Agenda." The Future of Parliament, Issues for a New Century, Ed. Philip Giddings, Houndmills, Basingstoke: Palgrave Macmillan, 2005. 3-11.

Searing, Donald D. "Foreword." Parliamentary Roles in Modern Legislatures, Ed. Magnus Blomgren and Olivier Rozenberg. London: Routledge, 2012. xxi-xxvii.

Tindale, Christopher W. Fallacies and Argument Appraisal. Cambridge: Cambridge UP, 2007.

Walton, Douglas. Informal Logic. A Handbook for Critical Argumentation. Cambridge: Cambridge UP, 1989.

Walton, Douglas. Fundamentals of Critical Argumentation. Cambridge: Cambridge UP, 2006.

Walton, Douglas. Dialog Theory for Critical Argumentation. Amsterdam: John Benjamins, 2007.

Walton, Douglas. Informal Logic, A Pragmatic Approach. $2^{\text {nd }}$ Ed. Cambridge: Cambridge UP, 2008.

Zarefsky, David. Argumentation - The Study of Effective Reasoning, Chantilly, VA: The Teaching Company, 2005.

Zarefsky, David. Political Argumentation in the United States. Amsterdam: John Benjamins, 2014. 


\section{Corpus Sources}

1. Druga Sednica Drugog redovnog zasedanja Narodne Skupštine Republike Srbije u 2018. godini - peti dan [The Second Sitting of the Second Regular Session of the National Assembly of the Republic of Serbia in 2018 - the fifth day].

http,//www.parlament.gov.rs/Druga_sednica_Drugog_redovnog_zase

danja_Narodne_skup\%C5\%A1tine_Republike_Srbije_u_2018._godini.3 4994.941.html

http, //www.parlament.gov.rs/national-assembly.467.html, accessed January $10^{\text {th }} 2019$.

2. MEPs' debate on long-term UK-EU relationship, published on 13 March 2018,

https,//www.youtube.com/watch?v=_6G2PLbhVcE\&t=2335s,

the minutes available at:

http,//www.europarl.europa.eu/sides/getDoc.do?pubRef=-

//EP//TEXT+PV+20180313+ITEM-

003+DOC $+X M L+V O / / E N \&$ language $=E N$, accessed January $26^{\text {th }} 2019$.

3. MEPs' debate on the situation in Hungary, published on 11 September $2018 \mathrm{https}, / /$ www.youtube.com/watch?v=ARfcG2FFi04, the minutes available at:

http,//www.europarl.europa.eu/sides/getDoc.do?pubRef=-

//EP//TEXT+PV+20180911+ITEM-

$011+D O C+X M L+V 0 / / E N \&$ language $=E N$, accessed January $26^{\text {th }} 2019$.

4. MEPs' debate on the UK's withdrawal from the European Union, published on 29 November, 2018

https,//www.youtube.com/watch?v=vflc5fRTKRQ \&t=1446s,

the minutes available at:

http,//www.europarl.europa.eu/sides/getDoc.do?pubRef=-

//EP//TEXT+PV+20181129+ITEM-

003+DOC+XML+VO//EN\&language $=E N$, accessed January $21^{\text {st }} 2019$.

5. Prime Minister's Questions, published on 12 December 2018, https,//www.youtube.com/watch?v=12oEfKWlym0, accessed January $10^{\text {th }} 2019$.

6. UK Parliament Debate on Brexit Draft Agreement with EU, published on 22 November 2018, https,//www.youtube.com/watch?v=sv2ZqDIvTLk, accessed January $10^{\text {th }} 2019$ 


\section{IRELEVANTNOST U DISKURSU PARLAMENATA EVROPSKE UNIJE, UJEDINJENOG KRALJEVSTVA I REPUBLIKE SRBIJE}

Rad predstavlja izveštaj o istraživanju nastalom na osnovu proučavanja nekih od jezičkih i logičko-retoričkih karakteristika debata u parlamentima Evropske unije, Ujedinjenog Kraljevstva i Republike Srbije u okvirima Voltonove (Walton 2008) neformalne logike (informal logic). Glavni fokus rada predstavlja analiza argumentacije u parlamentarnom diskursu koja se može okarakterisati kao kritika na osnovu irelevantnosti. Termin kritika je u radu uzet kao adekvatniji od termina logička greška, s obzirom na činjenicu da je uvek uputno zauzimanje kritičkog stava prema određenoj diskusiji pre nego što se neki argument diskvalifikuje ili mu se zameri da je posredi suštinska omaška. U tom smislu, za potrebe ovog istraživanja je ustanovljena posebna tipologija od 20 osnovnih oblika kritika irelevantnosti, koja je u skladu sa osobenostima komunikacije u okviru parlamentarnog diskursa, specifičnog epistemičkog žanra iz koga, prema očekivanjima, proističu adekvatna saznanja i rešenja za politička i zakonodavna pitanja na dnevnom redu sednice. Empirijski deo istraživanja zasniva se na multikulturalnom korpusu od gotovo 200 primera kritika sa osnovom irelevantnosti zabeleženih ne engleskom i srpskom jeziku, u okviru šest registrovanih parlamentarnih debata i njihovih denaturalizovanih transkripata. Posebna pažnja posvećena je pitanjima koja su razmatrana u relevantnim parlamentima u vezi sa događanjima u periodu nakon Bregzita (2018-2019). Analizom istraživačkog korpusa i kvantitativnom metodom, utvrđeno je da su centralni oblici irelevantnosti oni koji su zasnovani na prekidu logičkog sleda ili nisu zasnovani na premisama (non sequitur), a zatim i oni koji su upućeni na ličnost sagovornika (argumentum ad hominem). Dodatna implikacija je njihova frekvencija na 10.000 reči detektovana u debatama, koja sugeriše da je irelevantnost najprisutnija u parlamentu Evropske unije prilikom obraćanja poslanika i članova parlamenata tokom aktuelnih debata.

Ključne riječi: parlamentarni diskurs, relevantnost, irelevantnost, engleski, srpski 